\title{
Late Pleistocene brown bear (Ursus arctos) from the Caucasus
}

\author{
Gennady F. Baryshnikov
}

ABSTRACT. The examination of the fossil collections of teeth and bones of Ursus arctos from Paleolithic sites in Kudaro cave, South Ossetia, revealed the attribution of the Late Pleistocene material to the fossil subspecies $U$. a. binagadensis. The brown bear remains recovered in the layers dated by the end of Late Pleistocene is referred to the extant Caucasian subspecies U. a. meridionalis.

KEY WORDS: Ursus arctos, Ursidae, Pleistocene, Paleolithic cave sites, Caucasus.

Gennady F. Baryshnikov [g_baryshnikov@mail.ru], Zoological Institute, Russian Academy of Sciences, Universitetskaya nab. 1, Saint Petersburg 199034, Russia.

\section{Позднеплейстоценовый бурый медведь (Ursus arctos) с Кавказа}

\section{Г.Ф. Барышников}

\begin{abstract}
РЕЗЮМЕ. Исследование коллекции ископаемых зубов и костей Ursus arctos из Кударских палеолитических стоянок в Южной Осетии показало, что материалы из слоев позднего плейстоцена принадлежат к ископаемому подвиду $U$. a. binagadensis. Останки бурого медведя из слоев, датированных концом позднего плейстоцена и голоценом, отнесены к современному кавказскому подвиду $U . a$. meridionalis.
\end{abstract}

КЛЮЧЕВЫЕ СЛОВА: Ursus arctos, Ursidae, плейстоцен, палеолитические пещерные стоянки, Кавказ.

\section{Introduction}

Brown bear (Ursus arctos L., 1758), which is widely distributed now in Holarctic, was a characteristic representative of the Mammoth megafauna in the Late Pleistocene of Northern Eurasia. Meanwhile its fossil remains are found scarcer than those of cave bears, the morphological and taxonomical diversity of $U$. arctos in the Late Pleistocene remains poorly understood.

$U$. arctos is included into faunal lists of several Caucasian cave localities: Akhstyrskaya, Sakazhiya, Devis-Khvreli, Gvardzhilas-Klde, Verkhniya, Bronzovaya, Kudaro 1 and Kudaro 3 (Vereshchagin, 1959; Vekua, 1978). However, the number of its fossil remains is surprisingly small, especially, with regards of southern location and diversity of natural supplies of this mountain region. A scarcity of brown-bear finds may be explained by competition with more robust Kudaro cave bears (U. kudarensis Baryshnikov, 1985) keeping smaller brown bears out cave shelters. It should be mentioned that $U$. kudarensis is represented in $\mathrm{Ku}$ daro caves by several thousand fossil remains (Baryshnikov, 1999).

The Late Pleistocene brown bear from Caucasus has been described as a separate subspecies $U$. arctos binagadensis from the asphalt locality of Binagady near Baku in Azerbaijan (Vereshchagin, 1946). The type series consists of four immature individuals (lectotype: ZIN 23679-1, maxilla fragment with M1-M2;
Fig. 1). None of brown bears from other Caucasian sites was morphologically characterized.

Therefore, a special interest may be given to rather small fossil material of $U$. arctos from Kudaro 1 Cave and Kudaro 3 Cave in Southern Ossetia, which is for the first time described in detail in this study. The present communication continues a series of publications deal with the Pleistocene fauna of Carnivora from Kudaro Paleolithic sites (Baryshnikov, 2010a, b).

\section{Localities, material and methods}

Kudaro 1 Cave and Kudaro 3 Cave are situated on the left bank of the Dzhodzhori River (Rioni River

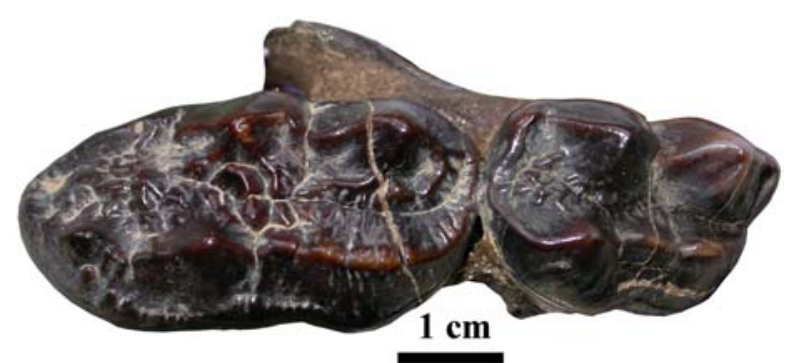

Figure 1. Right maxilla fragment with M1 and M2 of Ursus arctos binagadensis from Binagady, Azerbaijan (ZIN 236791, lectotype); occlusal view. 
Table 1. Measurements of mandibles of Late Pleistocene Ursus arctos.

\begin{tabular}{|c|c|c|c|c|c|c|}
\hline \multirow[t]{2}{*}{ Measurements, $\mathrm{mm}$} & \multirow{2}{*}{$\begin{array}{l}\text { Kudaro 3, } \\
\text { Caucasus } \\
\text { ZIN } 34595\end{array}$} & \multirow{2}{*}{$\begin{array}{c}\text { Eliseevichi, } \\
\text { European Russia } \\
\text { ZIN 23774-1 }\end{array}$} & \multirow{2}{*}{$\begin{array}{c}\begin{array}{c}\text { Monte Verde, } \\
\text { Italy }\end{array} \\
\text { IGPR } 1152 \\
\end{array}$} & \multicolumn{2}{|c|}{ Taubach, Germany } & \multirow{2}{*}{$\begin{array}{c}\text { Předmosti, } \\
\text { Czech } \\
\text { Republic }\end{array}$} \\
\hline & & & & SMW 448 & SMW 455 & \\
\hline Total length & 239.0 & 258.4 & 237.0 & - & - & - \\
\hline Length c1-m3 & 143.2 & 157.9 & 143.5 & 152.5 & - & 149.5 \\
\hline Length p4-m3 & 85.7 & 91.1 & 90.0 & 83.5 & 91.3 & 93.0 \\
\hline Height behind $\mathrm{m} 1$ & 40.0 & 50.6 & 43.7 & 47.3 & 49.8 & 44.9 \\
\hline Height in diastema & 39.7 & 49.0 & 44.0 & 47.7 & 51.1 & 46.3 \\
\hline \multicolumn{7}{|l|}{ Teeth } \\
\hline $\mathrm{c} 1 \mathrm{~L}$ & 20.9 & 22.6 & & 24.7 & & 28.0 \\
\hline $\mathrm{c} 1 \mathrm{~W}$ & 14.8 & 17.1 & & 16.1 & & 18.9 \\
\hline p4 L & 12.5 & 14.8 & 13.7 & & 15.3 & 14.6 \\
\hline $\mathrm{p} 4 \mathrm{~W}$ & 7.3 & 8.2 & 8.6 & & 9.2 & 8.0 \\
\hline $\mathrm{m} 1 \mathrm{~L}$ & 24.7 & 26.2 & 25.8 & & 26.0 & 27.5 \\
\hline $\mathrm{m} 1 \mathrm{~W}$ & 12.3 & 13.3 & 13.1 & & 14.6 & 14.0 \\
\hline $\mathrm{m} 2 \mathrm{~L}$ & 25.8 & 25.8 & 28.0 & & 28.8 & 27.6 \\
\hline $\mathrm{m} 2 \mathrm{~W}$ & 17.3 & 17.0 & 17.8 & & 19.3 & 17.7 \\
\hline $\mathrm{m} 3 \mathrm{~L}$ & & 24.4 & & & & 23.7 \\
\hline $\mathrm{m} 3 \mathrm{~W}$ & & 16.1 & & & & 16.1 \\
\hline
\end{tabular}

basin) near Kvaisa City in the Southern Ossetia and located at near $1600 \mathrm{~m}$ above sea level. The thickness of Pleistocene cave sediments including Acheulean (layer 5) and Mousterian (layers 3-4) stone industries (Lioubine, 1998). The Mousterian layer 3a is dated by radiocarbon to $44,150 \pm 2,400 / 1,850$ (Gr-6079) (Lioubine, 1998). Layers 1 and 2 belong to Holocene and final part of Pleistocene. Therefore, layers 2 and 3 are divided by significant temporal interval; in other Caucasian cave sites, this interval was a time of the accumulation of sediments containing Upper Paleolithic artifacts.

Fossil remains of $U$. arctos are found in upper layers 1-4 of both caves. The collection includes a single mandible, five isolated teeth, and several postcranial bones, which are partly broken. This material is kept in the Zoological Institute, Russian Academy of Sciences in Saint Petersburg, Russia (ZIN).

For comparison, collections from the Natural History Museum in London, UK (NHM), Aussenstelle Senckenbergmuseum in Weimar, Germany (SMW), National Museum in Prague, Czech Republic (NMP), Moravské Museum in Brno, Czech Republic (MMB), Instituto di Geologia e Paleontologia, Università "La Sapienza" in Rome, Italy (IGPR), and Institute of Zoology, Armenian Academy of Sciences in Yerevan, Armenia (IZA) were used.

Measurements of mandible and teeth were taken as described by Baryshnikov (2007). Limb bones measurements followed the scheme of von den Driesch (1976). The data were processed with the use of Factor Analysis from STATISTICA 6.0.

The following designations of measurements are used. Teeth: $L$ - length, $L t d$ - length of talonide; $W$ — width. Bones: $B d$ - breadth of the distal end; $B p-$ breadth of the proximal end; $D d-$ depth of the proxi- mal end; $G L$ — greatest length; $S D$ — smallest breadth of middle part of diaphysis.

\section{Description and comparisons}

Mandible. The left mandible (ZIN 34595, Kudaro 3 Cave, layer 4, horizon 1, 1974) does not differ by its size from mandibles of the Recent Caucasian brown bear (Tab. 1). The coronoid process is broken off (Fig. 2A). The symphiseal portion is rather short, without a pronounced "chin." The horizontal ramus is low, with straight ventral margin inconspicuously concave in the middle part, instead of being convex as in the Kudaro cave bear ( $U$. kudarensis). Preangular process is well developed. There are two mental foramens; the anterior one is situate below the postcanine diastema, whereas the posterior foramen is locate beneath $\mathrm{p} 4$.

Canine $\mathrm{c} 1$, alveolus of $\mathrm{p} 1$, tooth row $\mathrm{p} 4-\mathrm{m} 2$, and alveolus of $\mathrm{m} 3$ are preserved. The diastema between $\mathrm{p} 1$ and $\mathrm{p} 4$ is short. The canine is typical for brown bear in structure; its width measured at the crown base assigns ZIN 34595 to male. The specimen belonged to adult animal, since cheek teeth possess wear facets on the apices of tubercles.

Lower premolar 4 is short, without additional cusps (Fig. 2C-E). Well-developed lingual cingulid forms slight cuspids on the anterior and posterior margins of the tooth crown.

Lower carnassial tooth $\mathrm{m} 1$ is shorter than lower molar m2. Its metaconid consists of two tubercles. Talonid of $\mathrm{m} 1$ is wide, with distinct labial cingulid at the place of contact with the trigonid. The hypoconid is large; the entoconid is markedly worn, but with distinguishable fine additional cuspid (entoconulid) in front of it. 

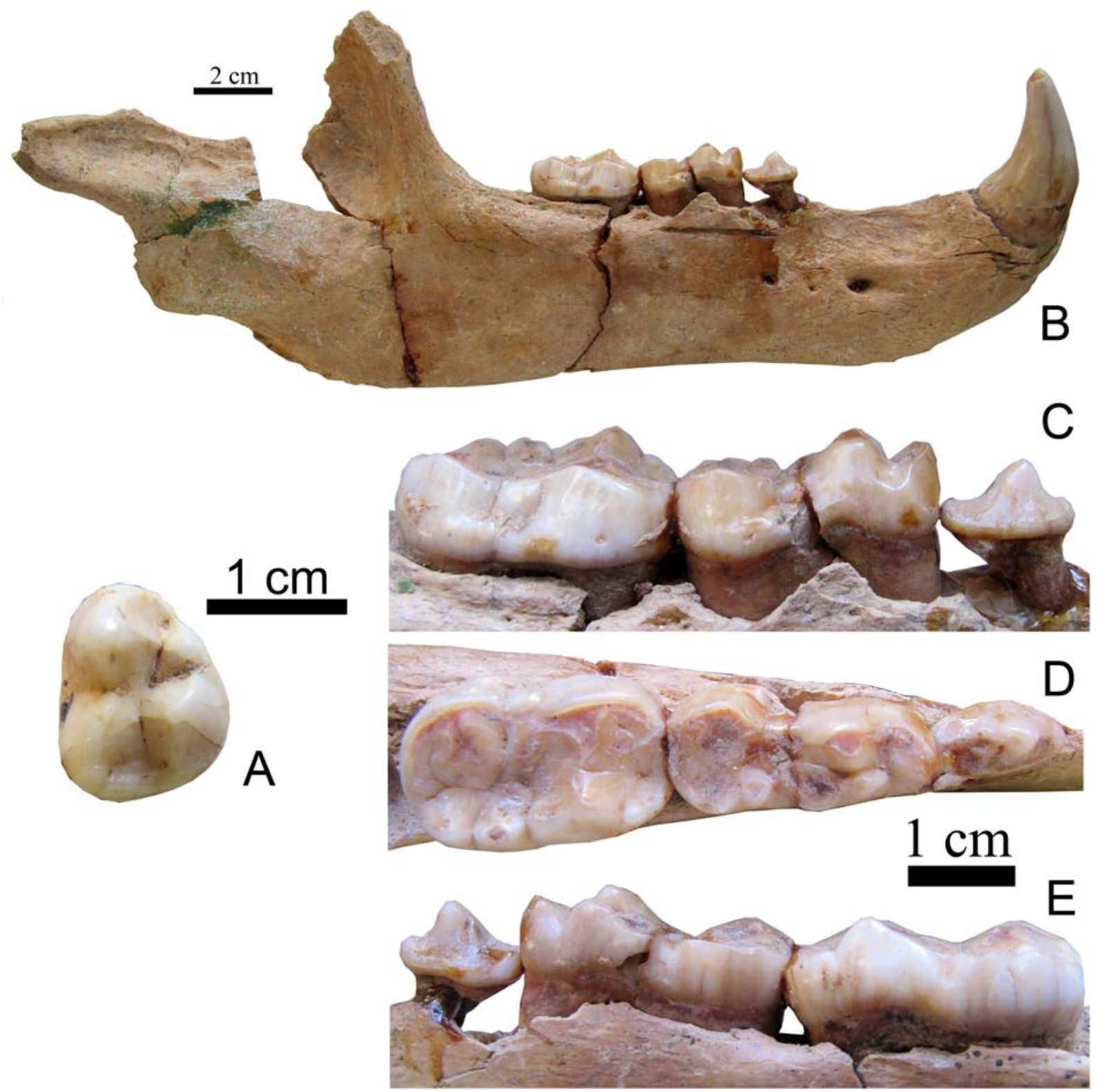

Figure 2. Mandible and teeth of Ursus arctos from Kudaro caves; labial (B, C), lingual (E) and occlusal (A, D) views. A P4, right (ZIN 36319), Kudaro 3, 1959; B — mandible, right (ZIN 34595), Kudaro 3, 1974; C, D, E — lower teeth p4-m3, right (ZIN 34595)

The talonid of lower molar $\mathrm{m} 2$ is slightly widened. The paraconid is absent; the metaconid is a single cusp. The entoconid consists of two cusps. A weak cingulid extends along the labial margin of the crown.

In the tooth morphology, the described specimen dos not differ from the Recent Caucasian brown bear (U. arctos meridionalis von Middendorff, 1851), in spite of its teeth being more robust (Tab. 1).

A principal components analysis, carried out on the basis of 11 mandible measurements included into Tab. 1 (with exception of the canine dimensions), comprises five samples. Factor 1 contains all measurements $(87.1 \%$ of dispersion); Factor 2 predominantly incorporates the total length. Within the scatterplot of Factor 1 and Factor 2, the Kudaro specimen is placed near the sample of Recent Caucasian subspecies U. a. meridionalis, which is located between samples of recent subspecies U. a. syriacus Hemprich et Ehrenberg, 1828 from Western Asia and U. a. pruinosus Blyth, 1854 from Tibet. Fossil mandible from Eliseevichi open site in European Russia occupies a more separate position (Fig. 3). Its robust size is comparable with that in the fossil $U$. 


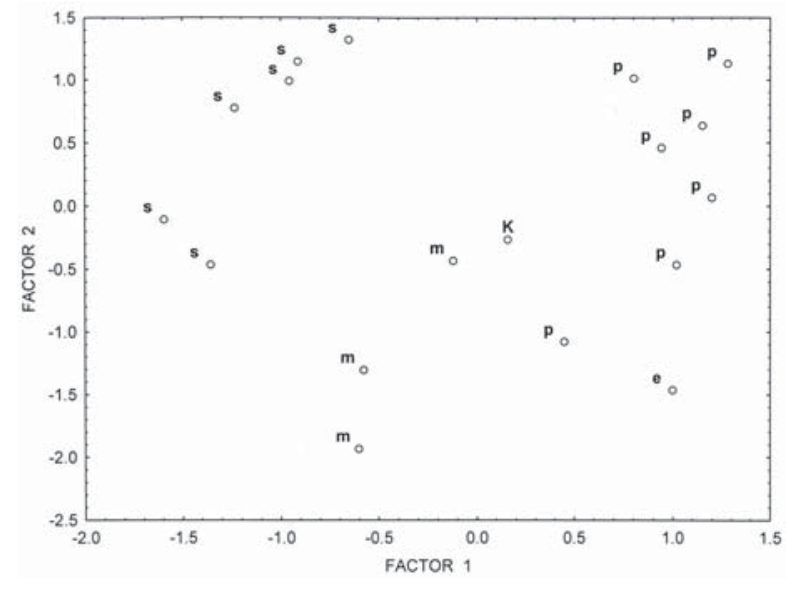

Figure 3. Plot of factor scores of Factor 1 and Factor 2 from principal components analysis of mandibles. U. arctos, Late Pleistocene: e - Eliseevichi, European Russia; k - Kudaro 3, Caucasus; U. arctos, Recent: $\mathrm{m}-U$. a. meridionalis; $\mathrm{p}-$ U. a. pruinosus; $\mathrm{s}-U$. a. syriacus.

arctos from Central Europe, e.g. from the locality of Př edmosti in Czech Republic.

Isolated teeth. Right upper canine C1 (ZIN 363131, Kudaro 1 Cave, mixed layers, 1974) by length (19.0 $\mathrm{mm})$ and width $(15.5 \mathrm{~mm})$ is similar to canine of Recent $U$. arctos. This specimen may be referred to a male.

Right upper premolar P4 (ZIN 36319, Kudaro 3 Cave, layer 3, horizon 2, 1959) is smaller in size compared with the Late Pleistocene teeth of $U$. arctos from Italy and Uzbekistan (Tab. 2). Its measurements correspond to mean values of the length (13.4-16.8, $\mathrm{M}=14.93$ $\mathrm{mm}, \mathrm{n}=22)$ and width (10.0-13.8, M=11.82 mm, $\mathrm{n}=22)$ of this premolar in $U$. a. meridionalis. Paracone is pronouncedly higher than metacone; the latter cusp is simple in structure. The metastyle is absent. The protocone is large and shifted backwards with respect to the carnassial notch; there is an additional cusp in front of the protocone (Fig. 2A). A rather small labial cingulum is developed.

Right lower canine c1 (ZIN 36313-4, Kudaro 1 Cave, mixed layers, 1961) is characterized by the length $(20.1 \mathrm{~mm})$ and width $(15.0 \mathrm{~mm})$, which are only slightly smaller than mandibular canine in ZIN 34595, also being attributed to a male. A structure of tooth root suggests that the specimen come from an immature specimen.

Two isolated carnassial tooth m1, left (ZIN 363132, Kudaro 1 Cave, mixed layers, 1977) and right (ZIN 36314, Kudaro 1 Cave, layer 1, 1961), were recovered from the uppermost (Holocene?) level of cave deposits. ZIN 36313-2 (length $21.2 \mathrm{~mm}$, trigonide length 13.1 $\mathrm{mm}$, width $10.3 \mathrm{~mm}$ ) and ZIN 36314 (length 21.1, trigonide length $12.0 \mathrm{~mm}$, width $10.5 \mathrm{~mm}$ ) are found to be noticeably smaller as compared to $\mathrm{m} 1$ from mandible ZIN 34595 (length 24.7, trigonide length $14.0 \mathrm{~mm}$, width $12.3 \mathrm{~mm}$ ).

The measurements of both isolated $\mathrm{m} 1$ correspond to mean values of length $(21.37,18.2-24.2 \mathrm{~mm}, \mathrm{n}=20)$ and width $(10.64,9.3-12.4 \mathrm{~mm}, \mathrm{n}=20)$ for this tooth in $U$. a. meridionalis. The length of $\mathrm{m} 1$ in the mandible ZIN 34595, on the contrary, exceeds maximum length in the sample of $\mathrm{ml}$ of the Recent Caucasian brown bear. It corresponds to $\mathrm{m} 1$ length in Aman-Kutan Cave in Uzbekistan (Tab. 3).

A principal components analysis, carried out on the basis of three $\mathrm{m} 1$ measurements for six samples revealed that in the scatterplot of Factor 1 and Factor 2 examined samples divided mainly by Factor 1 containing all measurements (92.4\% of dispersion). ZIN 34595 is well separated from the sample of $U$. a. meridionalis and is distributed near fossil teeth from Aman-Kutan Cave (Fig. 4). U. arctos from the Late Pleistocene of Europe (Eliseevici, Př estmosti) had more robust $\mathrm{m} 1$.

Thus the collection of the lower carnassial teeth $\mathrm{m} 1$ from Kudaro caves consists of two groups. The first

Table 2. Measurements (in mm) of upper premolar P4 of Late Pleistocene Ursus arctos.

\begin{tabular}{|c|c|c|c|c|c|}
\hline Localities & $\begin{array}{c}\text { Museum } \\
\text { number }\end{array}$ & $\begin{array}{c}\text { Greatest crown } \\
\text { length }\end{array}$ & $\begin{array}{c}\text { Length of } \\
\text { paracone }\end{array}$ & $\begin{array}{c}\text { Greatest } \\
\text { crown width }\end{array}$ & $\begin{array}{c}\text { Minimal length between } \\
\text { frontal ridge of protocone } \\
\text { and caudal side of crown }\end{array}$ \\
\hline Caucasus & & & & & 13.0 \\
\hline Kudaro 3 & ZIN 36319 & 14.6 & 8.6 & 11.5 & \\
\hline Italy & & & & & 13.2 \\
\hline Monte Cucco & IGPR 630 & 15.5 & 10 & 12.4 & 12.9 \\
\hline & IGPR 649 & 15.1 & 9.4 & 12.4 & 12.9 \\
\hline & IGPR 651 & 15.5 & 9.3 & 12.4 & 11.8 \\
\hline Uzbekistan & & & & & 14.9 \\
\hline Aman-Kutan & ZIN 25262-10 & 16.2 & 10.9 & 12.3 & 12.8 \\
\hline & ZIN 25262-29 & 17.5 & 11.3 & 14.2 & 14.8 \\
\hline & ZIN 25262-57 & 15.6 & 10.1 & 12.9 & 1.9 \\
\hline & ZIN 25262-63 & 16.7 & 10.6 & 13.4 & 15.5 \\
\hline & ZIN 25262-67b & 16.8 & 11.1 & 12.2 & \\
\hline & ZIN 25262-a & 17.2 & 11.5 & 14.1 & \\
\hline & ZIN 25262-b & 17.4 & 11.8 & 12.8 & \\
\hline
\end{tabular}


Table 3. Measurements (in mm) of lower molar $\mathrm{m} 1$ of Late Pleistocene Ursus arctos.

\begin{tabular}{|c|c|c|c|c|}
\hline Localities & $\begin{array}{l}\text { Museum } \\
\text { number }\end{array}$ & Greatest crown length & Length of trigonid & $\begin{array}{l}\text { Greatest crown } \\
\text { width }\end{array}$ \\
\hline \multicolumn{5}{|l|}{ Caucasus } \\
\hline Kudaro 3 & ZIN 34595 & 24.7 & 14.0 & 12.3 \\
\hline \multicolumn{5}{|l|}{ European Russia } \\
\hline Eliseevichi & ZIN 23774-1 & 26.2 & 17.1 & 13.3 \\
\hline \multicolumn{5}{|l|}{ Czech Republic } \\
\hline \multirow[t]{2}{*}{ Předmosti } & MMB n/n & 25.0 & 11.7 & 13.0 \\
\hline & MMB n/n & 23.9 & 11.9 & 11.5 \\
\hline \multirow[t]{3}{*}{$\begin{array}{l}\text { Chlupáčova slyi, } \\
\text { Koněprusy }\end{array}$} & NMP 1783 & 23.6 & 14.5 & 12.7 \\
\hline & NMP 2742 & 28.8 & 18.5 & 14.3 \\
\hline & NMP 1784 & 27.0 & 17.4 & 13.4 \\
\hline \multicolumn{5}{|l|}{ Germany } \\
\hline \multirow[t]{11}{*}{ Taubach } & SMW 460 & 27.0 & 16.4 & 14.3 \\
\hline & SMW 455 & 26.0 & 16.8 & 14.6 \\
\hline & SMW 836 & 27.9 & 17.3 & 14.7 \\
\hline & SMW 476 & 26.2 & 16.4 & 13.2 \\
\hline & SMW 747 & 28.1 & 18.1 & 12.8 \\
\hline & SMW 730 & 25.3 & 16.2 & 12.8 \\
\hline & SMW 796 & 26.7 & 16.3 & 13.1 \\
\hline & SMW 741 & 24.1 & 14.5 & 12.3 \\
\hline & SMW 726 & 24.3 & 15.6 & 12.4 \\
\hline & SMW 742 & 24.8 & 15.8 & 14.2 \\
\hline & SMW 763 & 28.2 & 17.5 & 14.2 \\
\hline \multicolumn{5}{|l|}{ Italy } \\
\hline Monte Verde & IGPR 1152 & 25.8 & 15.5 & 13.1 \\
\hline \multicolumn{5}{|l|}{ Gibraltar } \\
\hline \multirow[t]{2}{*}{ Genista Cave } & NHM 47677 & 25.7 & 16.8 & 13.0 \\
\hline & NHM 47678 & 25.4 & 16.0 & 12.4 \\
\hline \multicolumn{5}{|l|}{ Uzbekistan } \\
\hline \multirow[t]{9}{*}{ Aman-Kutan } & ZIN 25262-112 & 25.0 & 17.0 & 13.0 \\
\hline & ZIN 25262-24 & 24.0 & 14.8 & 12.2 \\
\hline & ZIN 25262-67 & 24.4 & 15.6 & 11.6 \\
\hline & ZIN 25262 & 24.4 & 15.3 & 11.8 \\
\hline & ZIN 25262 & 24.8 & 15.7 & 12.1 \\
\hline & ZIN 25262 & 24.4 & 15.8 & 12.9 \\
\hline & ZIN 25262 & 23.0 & 14.7 & 11.4 \\
\hline & ZIN 25262-28 & 24.2 & 16.5 & 14.0 \\
\hline & ZIN 25262-26 & 24.3 & 15.5 & 13.7 \\
\hline
\end{tabular}

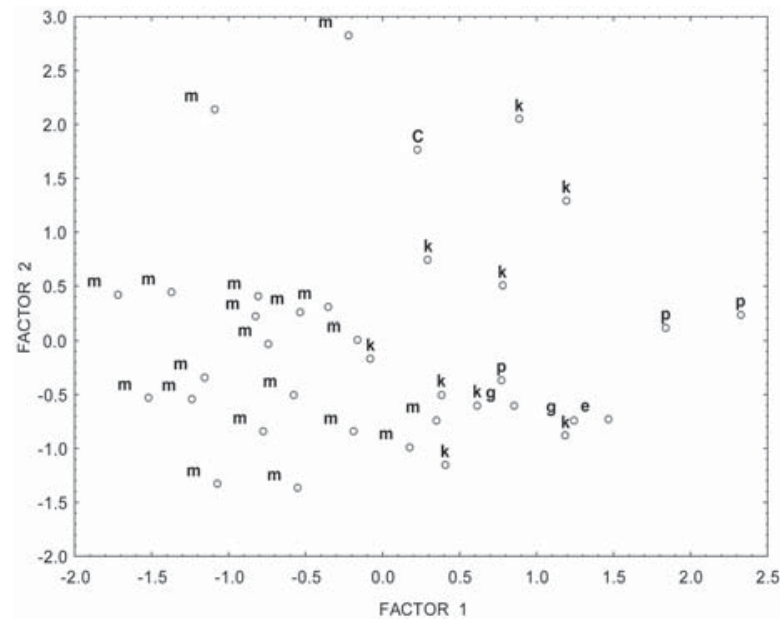

Figure 4. Plot of factor scores of Factor 1 and Factor 2 from principal components analysis of lower molar m1. U. arctos, Late Pleistocene: c - Kudaro 3, Russia; e - Eliseevichi, European Russia; g — Genista Cave, Gibraltar; k - AmanKutan, Uzbekistan; $\mathrm{p}$ - Př edmosti, Czech Republic; $U$. arctos, Recent: $\mathrm{m}-$ U. a. meridionalis. 
Table 4. Measurements (in mm) of metacarpals and metatersals of Late Pleistocene Ursus arctos.

\begin{tabular}{|c|c|c|c|c|c|c|c|}
\hline Bones & Museum numbers & GL & $\mathrm{Bp}$ & $\mathrm{Dp}$ & SD & $\mathrm{Bd}$ & $\mathrm{Dd}$ \\
\hline \multicolumn{8}{|c|}{ Metacarpals } \\
\hline \multicolumn{8}{|l|}{ Mtc 1} \\
\hline Kudaro 1 & ZIN 36316-1 & 59.2 & 19.8 & 22.1 & 9.1 & 15.7 & 12.6 \\
\hline Aman-Kutan & ZIN 25262 & - & 18.5 & 23.3 & - & - & - \\
\hline \multicolumn{8}{|l|}{ Mtc 2} \\
\hline Kudaro 1 & ZIN 36315-2 & 69.8 & 13.7 & 20.2 & 10.6 & 16.3 & 15.7 \\
\hline Aman-Kutan & ZIN 25262 & 80.9 & 16.6 & 24.7 & 11.9 & 19.2 & 17.2 \\
\hline \multicolumn{8}{|l|}{ Mtc 3} \\
\hline Kudaro 3 & ZIN 36317 & 76.1 & 17.7 & 23.7 & 13.1 & 19.4 & 16.8 \\
\hline Aman-Kutan & ZIN 25262-153 & - & 14.9 & 20.8 & - & - & - \\
\hline \multicolumn{8}{|c|}{ Metatarsals } \\
\hline \multicolumn{8}{|l|}{ Mtt 1} \\
\hline Kudaro 1 & ZIN 36315 & 55.9 & 23.4 & 24.8 & 10.3 & 15.3 & 13.3 \\
\hline \multicolumn{8}{|l|}{ Mtt 3} \\
\hline Kudaro 1 & ZIN 36316-4 & - & 14.4 & 22.9 & 12.3 & 17.7 & - \\
\hline Aman-Kutan & ZIN 25262-101 & - & 14.9 & 23.1 & 10.8 & - & - \\
\hline
\end{tabular}

group incorporates the specimen in mandible ZIN 34595 from layer 4 . The second group includes teeth from latest layers 1-2; these teeth do not differ in size from the teeth of the Recent $U$. a. meridionalis.

The lower cheek teeth are not present in the type material of $U$. a. binagadensis. Two upper molars M1 (length 25.0 and $25.3 \mathrm{~mm}$, width 17.4 and $15.1 \mathrm{~mm}$ correspondingly) from Binagady locality exceed by the length those of the Recent bear from Caucasus (20.46 $\mathrm{mm}, 18.0-23.8 \mathrm{~mm}, \mathrm{n}=20)$. The length of the upper molar M2 (length $38.5 \mathrm{~mm}$, width $18.8 \mathrm{~mm}$ ) from Binagady also somewhat greater than the maximum value of this measurement in the recent sample $(34.23 \mathrm{~mm}, 30.5$ $38.0 \mathrm{~mm}, \mathrm{n}=20$ ). Therefore, the cheek teeth from Binagady as well as cheek teeth from Kudaro 3 Cave (layer 4) appeared to be more robust as compared to those of the Recent Caucasian brown bear. Both examined fossil samples revealing resembles with each other may be referred to the fossil subspecies $U$. a. binagadensis.

Postcranial bones. The material from Kudaro caves contains three metacarpals: two right bones (ZIN $36316-$ 1, Kudaro 1 Cave, layer 3ab-2, 1984; ZIN 36317; Kudaro 3 Cave, layer 3c, horizon 2, 1978) and one left bone (ZIN 36315-2, Kudaro 1 Cave, layer 2, horizon 1, 1980). This collection also includes two metatarsals, right (ZIN 36315, Kudaro 1, layer 2, 1959) and left (ZIN 36316-4, Kudaro 3 Cave, layer X, horizon 3, 1978). The measurements of the metacarpal and metatarsal bones are given in Tab. 4. The measurements are similar to the corresponding metric characteristics of the fossil brown bear from Aman-Kutan Cave in Uzbekistan. The specimens of brown bear found in the Kudaro caves are smaller and more slender in comparison with those bones of Kudaro cave bear (U. kudarensis). In addition, examined specimens of brown bear possess no concavity on the articulatory ridge of the distal portions, which is characteristic of the $U$. kudarensis.

There are four astragali (Fig. 5A-E): two right bones, ZIN 36318 (Kudaro 1 Cave, layer 4, 1957; length 39.7 mm, breadth $44.5 \mathrm{~mm}$ ), ZIN 36312-2 (Kudaro 3 Cave, mixed layers, 1979; length $37.2 \mathrm{~mm}$, breadth $40.2 \mathrm{~mm}$ ) and two left bones, ZIN 36312-1 (Kudaro 3 Cave, mixed layers, 1978 ; length $41.1 \mathrm{~mm}$, breadth $45.7 \mathrm{~mm}$ ), ZIN 36313 (Kudaro 1 Cave; mixed layers, 1977; length $37.1 \mathrm{~mm}$, breadth $41.7 \mathrm{~mm}$ ). In the size and structure, the fossil specimens do not differ from astragali of the recent $U$. arctos. In Kudaro cave bear (U. kudarensis) the astragalus is larger, with wide rough platform bordering the articular area (trochlea tali) along the upper and interior sides; this platform is inconspicuously developed in brown bear. In addition, brown bear fossil astragali from Kudaro caves have a broad bridge between inner and lower calcaneus facets, which distinguishes brown bears from cave bears (Gromova, 1960).

The baculum (ZIN 36316-5, Kudaro 1 Cave, layer 2a, 1984) is measured $193.2 \mathrm{~mm}$ in length (Fig. 5G). Its size and structure resemble those of baculum in the Recent $U$. arctos. This find confirms the presence of males of brown bear in the paleontological material from the from Kudaro caves, which was hypothesized on the basis of metric characteristics of upper and lover canines.

\section{Discussion and conclusion}

The study carried out reveals that fossil remains of $U$. arctos from Kudaro caves are found in stratigraphical levels dated by the Late Pleistocene. Other Caucasian material has similar geological age. For example, the Binagady, which is a type locality of the fossil subspecies $U$. a. binagadensis (Vereshchagin, 1946), is usually dated as latest Interglacial (Eem) (Baryshnikov, 2002).

All specimens with identifiable gender belong to males. Presumably, females did not treated large Kudaro caves as safety winter dens, selecting for overwintering more concealed places. 

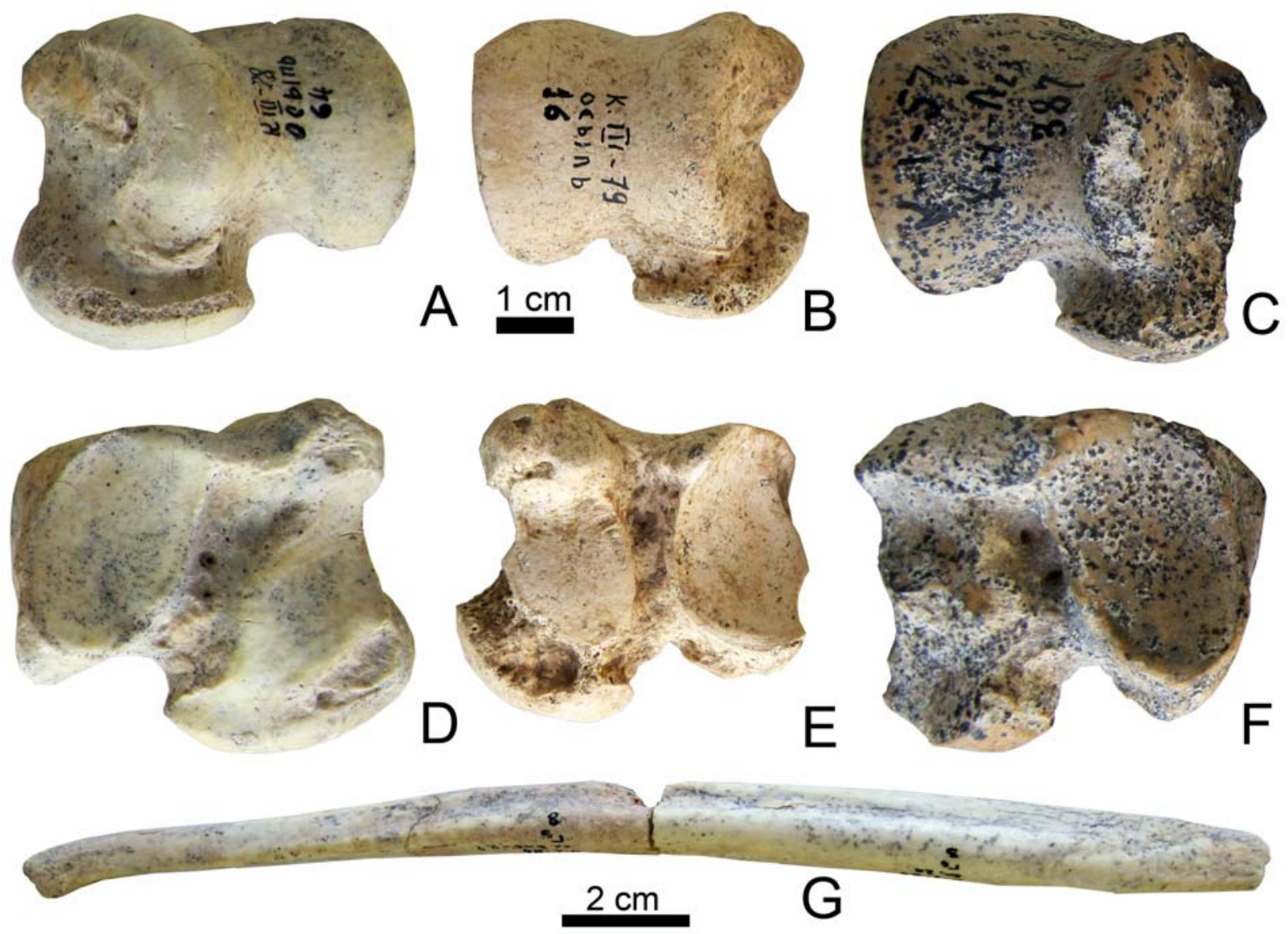

Figure 5. Astragali (A-F) and baculum (os penis) (G) of Ursus arctos from Kudaro caves; dorsal (A-C), ventral (D-F) and lateral (G) views. Astragalus, left: A, D - ZIN 36312-1, Kudaro 3, 1978; astragali, right: B, E - ZIN 36321-2, Kudaro 1, 1979; C, F — ZIN 36318, Kudaro 1, 1957; baculum: G - ZIN 36316-5, Kudaro 1, 1984.

Of two stratigraphical groups established for fossil brown bear from Kudaro caves, the first group (layers 3-4) is referred to $U$. a. binagadensis, based on the dental morphometry. This subspecies presumably comprises all finds of brown bear from the Late Pleistocene of Southern Caucasus. The second group consists of fossils from uppermost levels of Kudaro caves (layers 1-2). Metric characteristics of cheek teeth allow attribution of this material to the extant subspecies $U$. $a$. meridionalis.

Holocene shore deposits of Sevan Lake (Tsemakarbert) in Armenia were the place of finding the skull of brown bear (IZA 78, holotype; Fig. 6) described as the subspecies $U$. arctos sevanensis (Mezhlumian, 1959). Dimensions of upper cheek teeth of the type specimen are as follows (mm): M1 length 21.1, width 15.9; M2 length 31.5 , width 17.0. These measurements do not exceed limits of variation of molars in the recent Caucasian brown bear. U. a. sevanensis is regarded here as a junior synonym of $U$. a. meridionalis.

The study of mitochondrial DNA revealed that Recent Caucasian brown bears together with bears from
Eastern Europe and Asia form a one clade. Within this clade, bears from the Greater Caucasus represent a subclade, which diverged from a group of Eurasian brown bears nearly 19,800 BP that coincides with the Last Glacial Maximum (Murtskhvaladze et al., 2010).

Thus, molecular data testify the appearance of the subspecies $U$. a. meridionalis in Caucasus in the end of Late Pleistocene. This conclusion corresponds to the results of paleontological study of the material from Kudaro caves, resulting in finds of $U$. a. meridionalis only within the uppermost levels of the examined sites. The predecessor of this subspecies in the Southern Caucasus was the fossil subspecies U. a. binagadensis.

The Recent Caucasian brown bear shows considerable craniometrical variability, which served a basis to different views on its intraspecific taxonomy.

Some researchers referred Caucasian brown bears to the single subspecies U. a. syriacus, which is occurring in Western Asia (Adlerberg, 1935; Ellerman \& Morrison-Scott, 1951). Other taxonomists accepted two subspecies: $U$. a. meridionalis von Middendorff, 1851 (including $U$. a. caucasicus Smirnov, 1919) and $U$. $a$. 


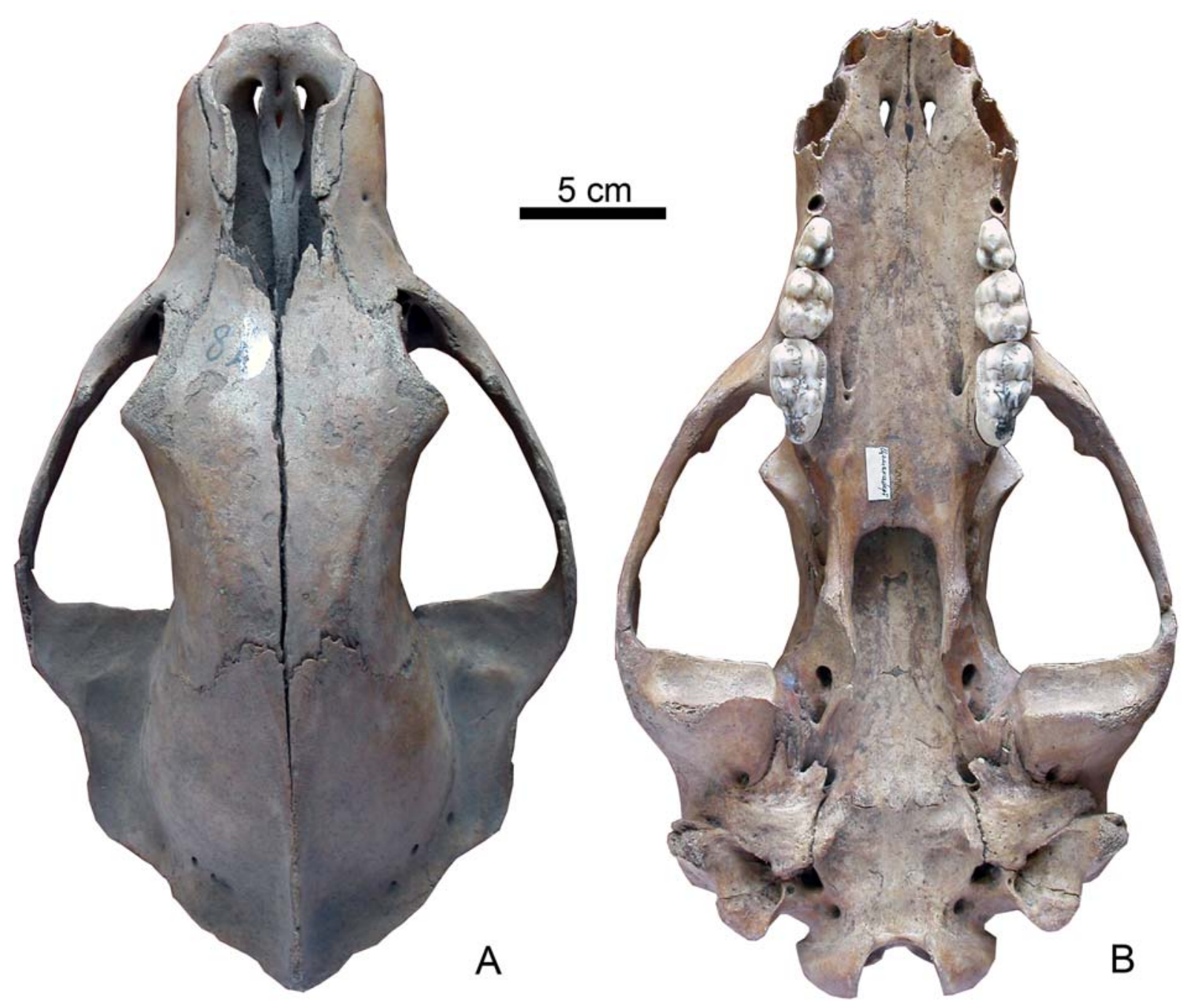

Figure 6. Skull of Ursus arctos sevanensis from Tsemakarbert, Sevan Lake, Armenia (IZA 78, holotype); dorsal (A) and basal (B) views.

syriacus Hemprich et Ehrenberg, 1828 (Ognev, 1931; Bobrinsky et al., 1944; Novikov, 1956; Heptner et al., 1967). It should be mentioned that $U$. a. syriacus was treated to comprise bears from southernmost areas of the region. Arabuli (1986) supplemented taxonomic composition of Caucasian brown bears with nominotypical subspecies $U$. a. arctos L., 1758 .

The results of molecular study show no essential difference between brown bears of Great and Minor Caucasus, comparing them with the nominotypical subspecies U. a. arctos (Murtskhvaladze et al., 2010). However craniometrical analysis revealed that Caucasian bears are well distanced from the bears of the European Russia (U. a. arctos) as well as from West Asian bears (U. a. syriacus), being referred to another subspecies, U. a. meridionalis (Baryshnikov, 2007). A considerable craniometrical variability Caucasian bears may be explained by the existence of several ecological-morphological groups (ecomorphs) in the Cauca- sus, the differences between them being adaptive (Lobachev et al., 1988; Chestin \& Mikeshina, 1998).

As a conclusion, I reconstruct the Late Pleistocene to be a time of occurrence in the Southern Caucasus of coarse-tooth brown bear belonging to the subspecies $U$. a. binagadensis Vereshchagin, 1946. During Last Glacial Maximum, brown bears dispersed here from the Eastern Europe, forming the subspecies U. a. meridionalis von Middendorff, 1851, which survived in Caucasus till the recent time.

ACKNOWLEDGEMENTS. The material for examination and comparison has been provided by Prof. V. Lioubine (St. Petersburg), Dr. A. Current (London), Dr. V. Eisenmann (Paris), Dr. R.-D. Kahlke (Weimar), Dr. J. Wagner (Prague), Dr. M. Galetová (Brno), Prof. C. Petronio (Roma) and Dr. N. Manaserian (Yerevan). My wife Svetlana Baryshnikova assisted me in my study.

The study is financially supported by Russian Foundation for Basic Research (grant \# 09-04-01770-a). 


\section{References}

Adlerberg G.P. 1935. [Bears of Caucasus. Systematic review] // Izvestiya Akademii Nauk SSSR. Otdelenie matematicheskikh i estestvennykh nauk. No.1. P.73-100 [in Russian].

Arabuli A.B. 1986. [About intraspecific variation of brown bear of Georgia] // Izvestiya Akademii Nauk GSSR. Seriya Biologicheskaya. T.12. No.6. P.409-415 [in Russian].

Baryshnikov G. 1999. Bone assemblages from Acheulean and Mousterian levels in the Kudaro Caves in the Caucasus Mountains // The Role of Early Humans in the Accumulation of European Lower and Middle Palaeolithic Bone Assemblages. Monographien des romisch-germanischen Zentralmuseums, Mainz. Bd.42. P.237-253.

Baryshnikov G.F. 2002. Local biochronology of Middle and Late Pleistocene mammals from the Caucasus // Russian Journal of Theriology. Vol.1. No.1. P.61-67.

Baryshnikov G.F. 2007. [Bears (Family Ursidae)]. SanktPeterburg: Nauka. 542 pp. [in Russian].

Baryshnikov G.F. 2010a. Middle Pleistocene Ursus thibetanus (Mammalia, Carnivora) from Kudaro caves in the Caucasus // Proceeding of the Zoological Institute RAS. Vol.314. No.1. P.67-79.

Baryshnikov G.F. 2010b. Pleistocene Mustelidae (Carnivora) from Paleolithic site in Kudaro Caves in the Caucasus // Russian Journal of Theriology. Vol.8. No.2. P.75-95.

Bobrinsky N.A. Kuznetsov B.A. \& Kuzyakin A.P. 1944. [Key for Mammals of USSR]. Moskva: Sovetskaya Nauka. 440 pp. [in Russian].

Driesch A., von den. 1976. A guide to the measurement of animal bones from archaeological sites // Peabody Museum Bulletin. No.1. P.1-136.

Ellerman J.R. \& Morrison-Scott T.C.S. 1951. Checklist of Palaearctic and Indian Mammals, 1758 to 1946. London: British Museum (Natural History). 810 pp.

Chestin I. \& Mikeshina N. 1998. Variation in skull morphology of brown bears (Ursus arctos) from Caucasus // Journal of Mammalogy. Vol.79. No.1. P.118-130.
Gromova V. 1960. [Determination key to mammals of USSR based on postcranial bones. Part 2. Determination key based on large tarsal bones]. Moskva: Izdatel'stvo Akademii Nauk SSSR. 118 pp. [in Russian].

Heptner V.G., Naumov N.P., Yurgenson P.B., Sludsky A.A., Chirkova A.F. \& Bannikov A.G. 1967. [Mammals of Soviet Union. T.2. Parts 1. Sea Cows and Carnivores]. Moskva: Vysshaya Shkola. 1004 pp. [in Russian].

Lobachev V.S., Chestin I.E., Kudaktin A.N. \& Fomin S.V. 1988. [Character of territorial utilization of bears from different ecomorph in Western Caucasus] // Byulleten' Moskovskogo Obshchestva Ispytatelei Prirody. Otdelenie Biologicheskoe. T.93. No.1. P.23-33 [in Russian].

Mezhlumian S.K. 1959. [Bear from beach settlements of Sevan Lake] // Izvestiya Akademii Nauk Armyanskoi SSR. Vol.12. No.4. P.85-88 [in Russian].

Murtskhvaladze M., Gabashelishvili A. \& Tarkhnishvili D. 2010. Geographic and genetic boundaries of brown bear (Ursus arctos) population in the Caucasus // Molecular Ecology. Vol.19. No.9. P.1829-1841.

Novikov G.A. 1956. [Carnivorous Mammals of USSR Fauna]. Moskva-Leningrad: Izdatel'stvo Akademii Nauk SSSR. 295 pp. [in Russian].

Ognev S.I. 1931. [Mammals of Eastern Europe and Northern Asia]. T.2. Moskva-Leningrad: Glavnauka. 776 pp. [in Russian].

Vekua A.K. 1978. [Fossil vertebrates from Tsutskhvati caves] // (Davitaya F.F., ed.) Izuchenie Peshcher Kolkhidy. Tsutskhvatskaya Mnogoyarusnaya Karstovaya Peshchernaya Sistema. Tbilisi: Metsniereba. P.94-126 [in Russian].

Vereshchagin N.K. 1947. [New race of brown bear from Binagady asphalt (Ursus arctos binagadensis, susp. nova) // Doklady Akademii nauk Azerbaidzhanskoi SSR. T.2. No.8. P.346-348 [in Russian].

Vereshchagin N.K. 1959. [Mammals of Caucasus. History of Fauna Origin]. Moskva-Leningrad: Izdatel'stvo Akademii Nauk SSSR. 704 pp. [in Russian]. 